\title{
Research Paper \\ Effectiveness of Child-Centered Mindfulness Therapy on 8-12 Year-Old Children with Depression Symptoms
}

Laleh Hoseini ${ }^{1}$, Gholamreza Manshaei ${ }^{* 2}$

1. M.A. in Psychology, Isfahan (Khorasgan) Branch, Islamic Azad University, Isfahan, Iran 2. Associate Professor, Department of Psychology, Isfahan (Khorasgan) Branch, Islamic Azad University, Isfahan, Iran

Citation: Hoseini L, Manshaei G. Effectiveness of child-centered mindfulness therapy on 8-12 year-old children with depression symptoms. Quarterly Journal of Child Mental Health. 2020; 7(1): 245-256.

http://dx.doi.org/10.29252/jcmh.7.1.21

\section{A R T I C L E I N F O}

\section{Keywords: \\ Mindfulness, anxiety, depression}

Received: 18 May 2018 Accepted: 4 Mar 2020 Available: 20 Jun 2020

\begin{abstract}
A B S T R A C T
Background and Purpose: Depression as a common mental disorder, can seriously damage the communicative, academic, developmental, and psychological processes of the children. Therefore the present study was conducted to investigate the effectiveness of child-centered mindfulness therapy on 8-12 year-old children with depression signs.

Method: This study was a quasi-experimental pretest-posttest control group design with 45-day follow-up period. The study population included all the male and female 8-12 year-old children with depression symptoms who had referred to the psychological consultation centers affiliated to the Education Administration in Isfahan city in 2017. A sample of 30 children out of this population was selected by convenience method and then randomly assigned to either the experimental or the control group. The experimental group received 10 weekly sessions of mindfulness-based intervention for 2.5 months, whereas the control group underwent no intervention. The applied instruments included Children's Depression Inventory (Kovacs, 1992) and Anxiety Scale for Children (March et al., 1997). Data were analyzed by repeated measures ANOVA.

Results: Data analysis showed that mindfulness-based therapy was significantly effective in reducing the anxiety of 8-12 year-old children with depression symptoms ( $\mathrm{p}<0.001)$. Moreover, results showed that effects of this therapy were significantly persistent during the time $(\mathrm{p}<0.001)$.

Conclusion: Based on the results of the present study, it can be concluded that whereas mindfulness is a meta-awareness feeling free from prejudice which leads to observance and acceptance of body phenomena and emotions as they are, it can help children with depression to accept their physical, emotional, and psychological signs and feelings and reduce their hypersensitivity towards them.
\end{abstract}

\footnotetext{
* Corresponding author: Gholamreza Manshaei, Associate Professor, Department of Psychology, Isfahan (Khorasgan) Branch, Islamic Azad University, Isfahan, Iran.

E-mail addresses: Smanshaee@yahoo.com
} 


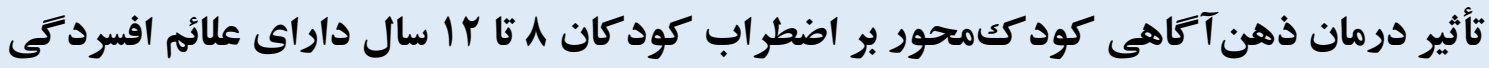

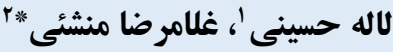

1. كارشناسى ارشد روانشناسى، واحد اصفهان (خوراسكان)، دانشكاه آزاد اسلامى، اصفهان، ايران.

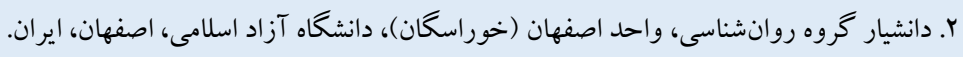

\section{جكيده}

زمينه و هدف: افسردگى به عنوان اختلال روانى رايج، مىتواند فرايند ارتباطى، تحصيلى، تحولى، و روانشناختى كود كان را با آسيب

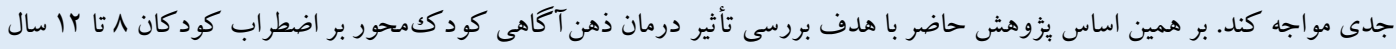
داراى علائم افسردىى انجام شد.

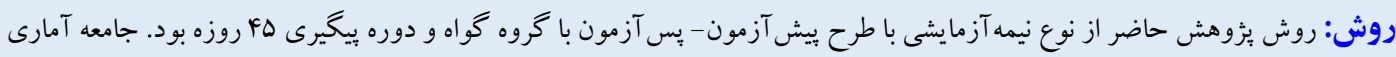

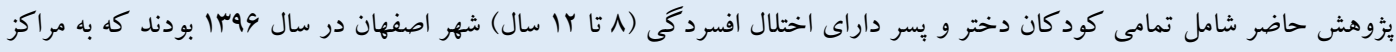

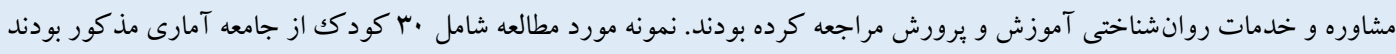

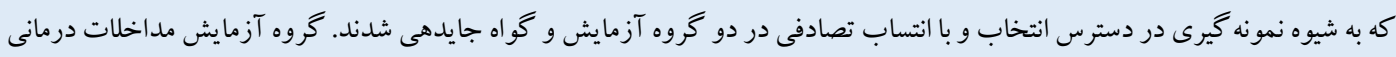

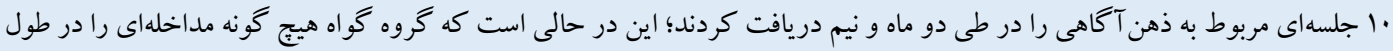

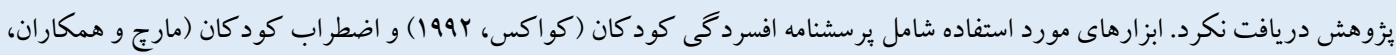

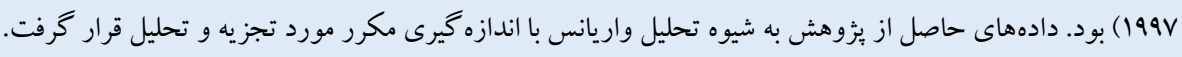

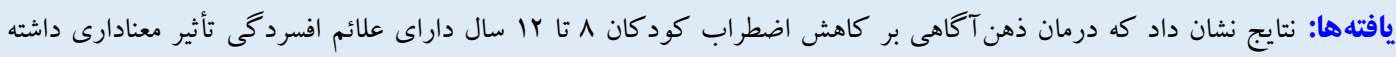

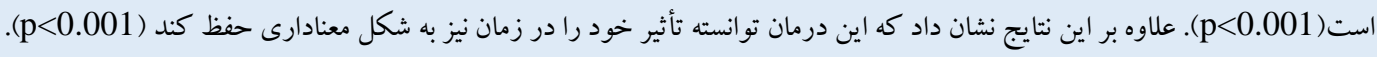

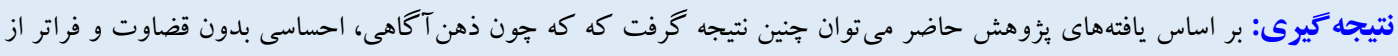

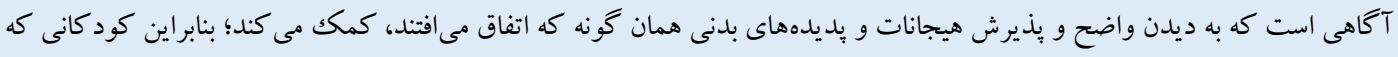

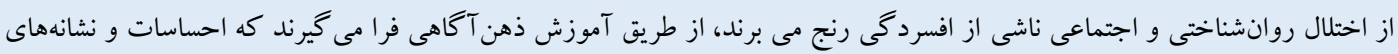

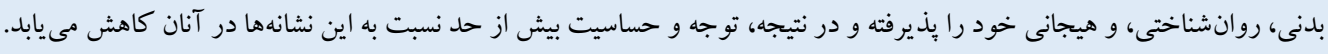

مشخصات مقاله

كليدوازهها:

ذهن Tكاهى، اضطراب،

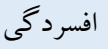

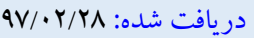

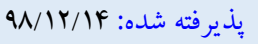

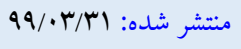

* نويسنده مسئول: غلامرضا منشئى، دانشيار كروه روانشناسى، واحد اصفهان (خوراسگان)، دانشكاه آزاد اسلامى، اصفهان، ايران.

رايانها: Smanshaee@yahoo.com

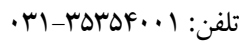




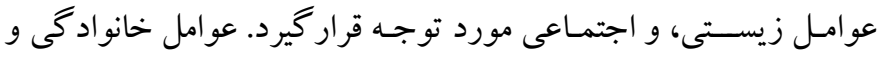

مقدمه

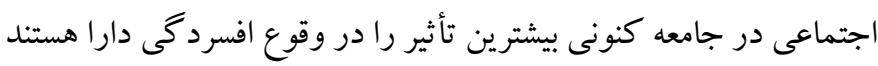

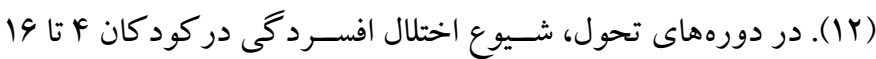

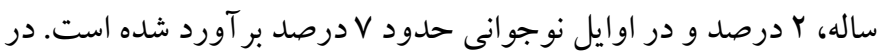

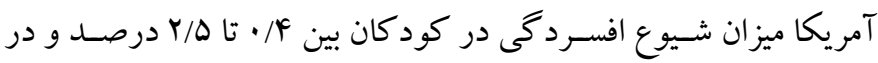

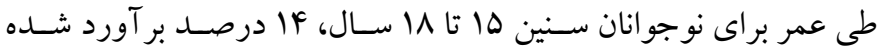

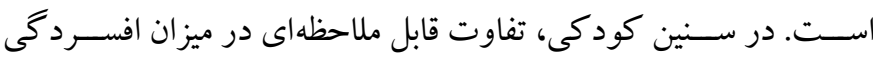

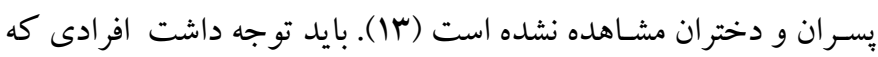

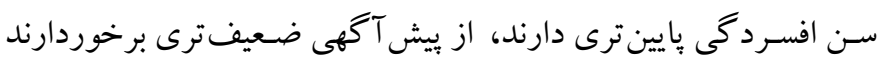

بروز افسردگگى، معمولاً با اضطر اب نيز همراه اسـت (ها). اضطر اب

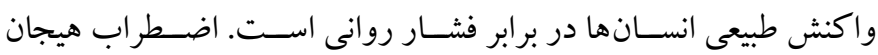

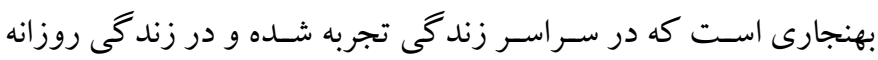
افراد نقش حفاظتى دارد. اين هيجان در حد متعادل و سازنده فرد راوادار

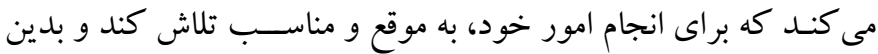

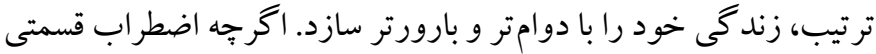

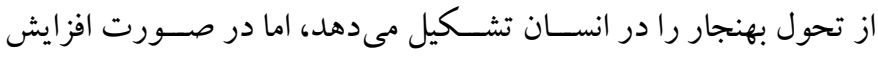
شـدت و طول مدت آن، به مشكل جدى و تهديد واقعى تبديل مى شود (19 و 1V)؛ بـه طورى كه بى تفاوت بودن و رها كردن آن بدون درمان ،

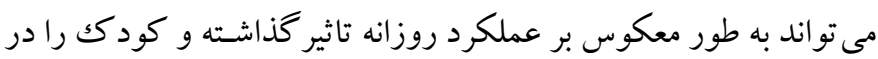
معرض حرمت خود بايين، روابط اجتماعى ضعيف، و شكست تحصيلى

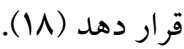
روشهاى مداخلهاى متعددى براى بهبود افسـردگى كود كان انجام

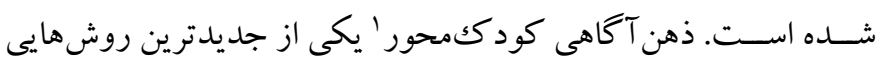

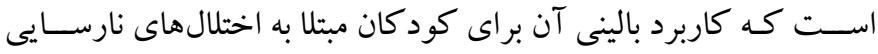
توجه فزون كنشى'، افسردگى، اضطراب، اختلال تنيدگى يس از سانحهّ؛

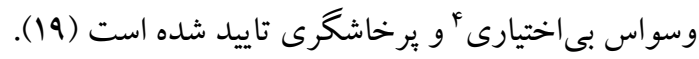

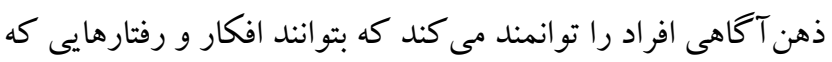

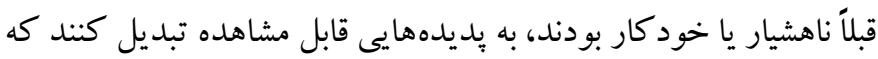
در بدن يا ذهن خود آنها در حال وقوع هسـتند (·r). اين سـازه به عنوان

اختلال افسردگى از مهمترين انواع اختلالات خلقى به شمار مىرود كه به

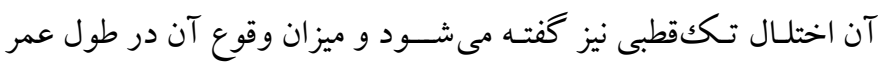

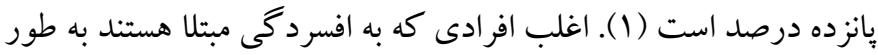

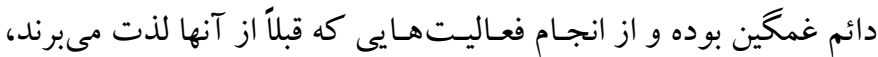
ديخر خوشــنود نبوده يا تر كيبى از دو حالت فوق را تجربه مى كنند (Y).

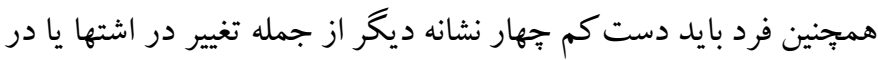

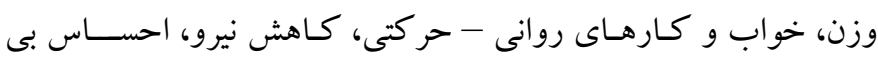

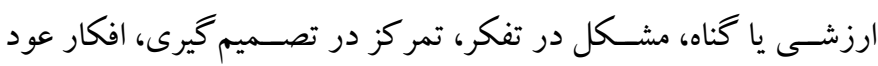

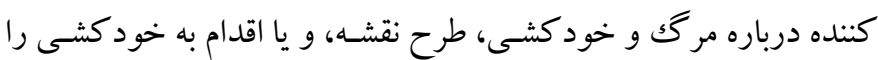

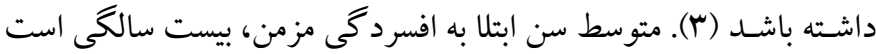

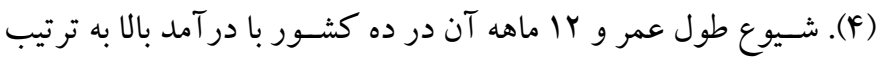

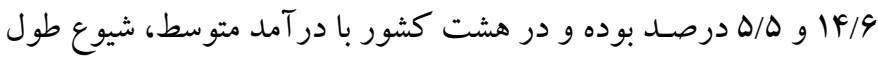

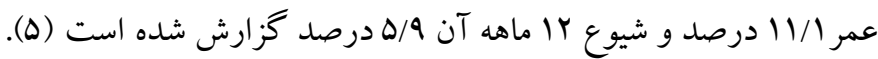

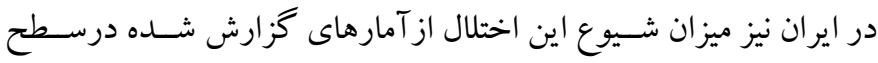
جهانى بيشتر است؛ به طورى كه ميزان شيوع افسردگى خفيف، متوسط،

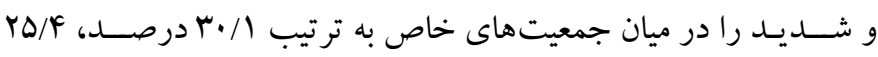

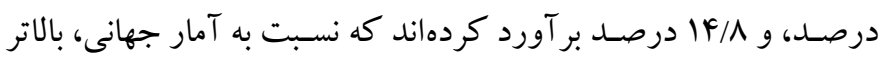
(9) (9) (9) (9)

آغاز زودهنگام افسـردگى در كودكى، شـكل وخيم بيمارى بوده و كود كان نسـبت به بزر گسـالان، تعداد بيشـترى از دورههاى عود رور را تجربه

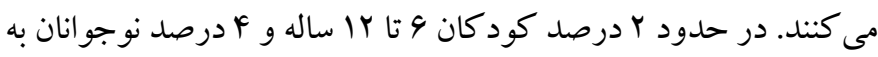

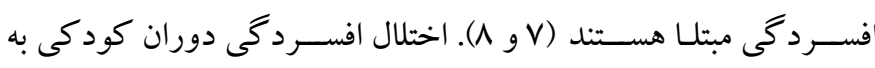
كونسهاى منفى بر عملكرد شــخصى و خانو ادكى بهنجار كود كك تأثير

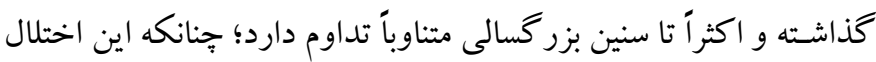

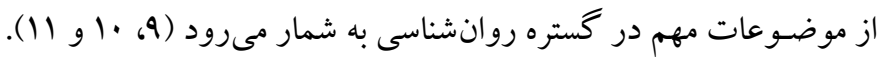

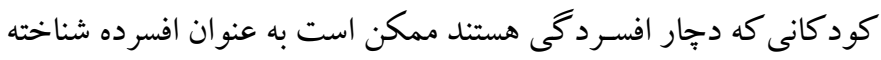

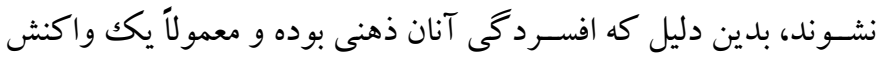

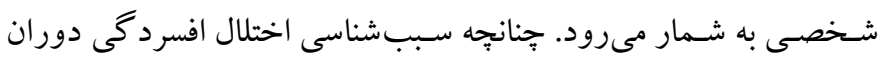

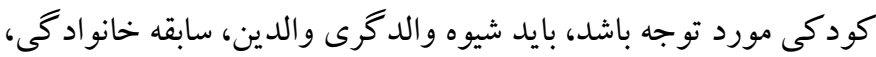


اجتنابنايذير اســ؛ زيرا كه اين گروه از جامعه در آينده نزديكك بايد به ايفاى نقش اجتماعى و شـلى ببردازند و آسيب بذيرى روانشناختى رئى آنان سبب مىشود نتواند كار كرد اجتماعى، روانشناختى، و تحصيلى مناسب ليبردي را از خود بروز دهند. از سويى ديخر بايد يادآور شد كه درمان ذهن آكاهى كود ككمحور،

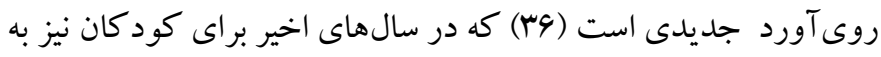

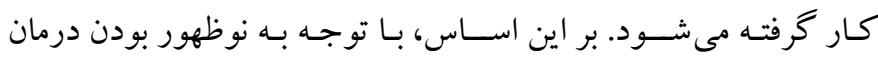

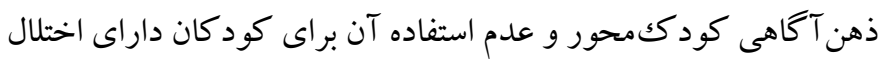

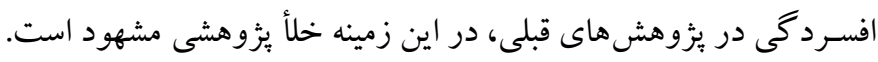

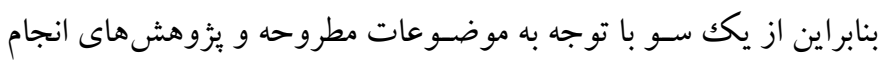

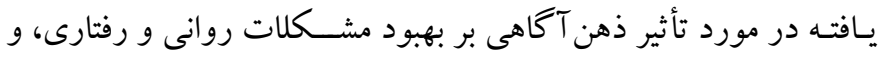

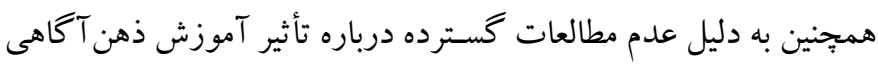

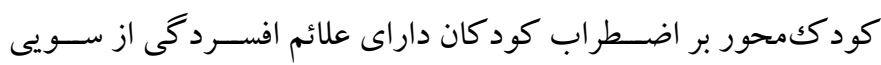

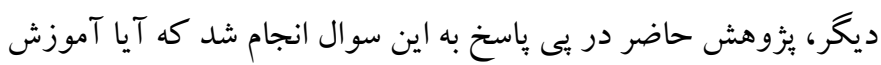

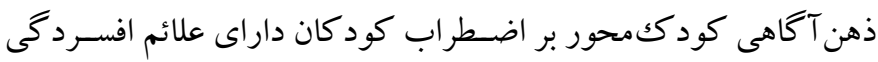
تأثير دارد؟

روش

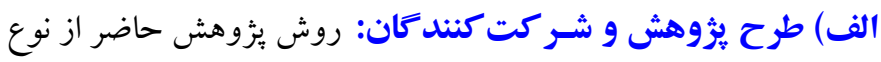

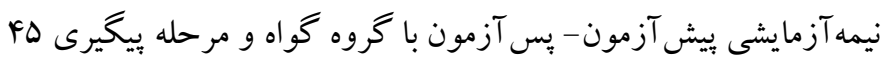

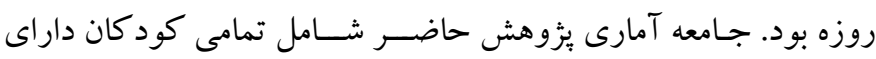

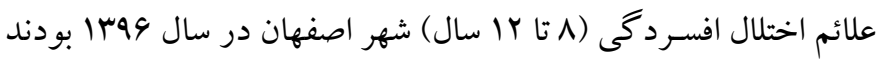

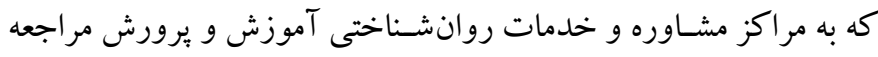
كرده بودند. در اين بثزوهش از روش نمونه گيرى در دسترس استفاده شد.

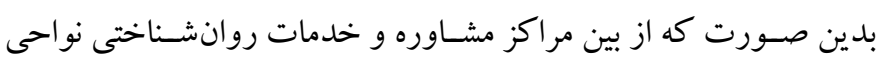

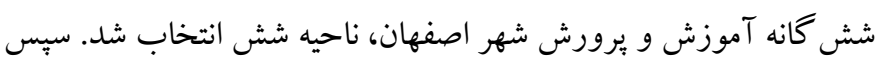

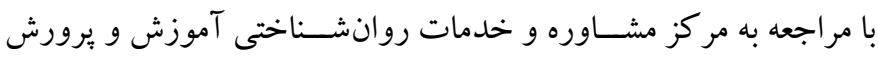
ناحيه شـش اصفهان، از مسـؤولان اين مركز درخواسـت شد كه كود كان

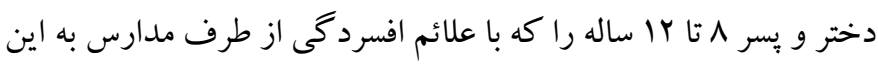

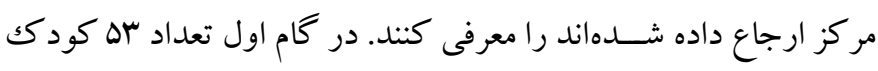

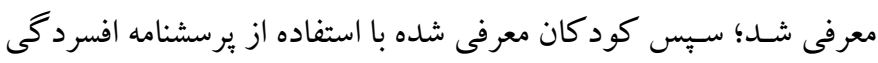

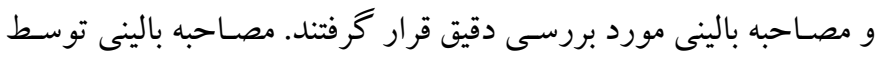

توجـه كردن بـه شـــوهاى خـاص، هدفمند، در زمان حاضــر و خالى از

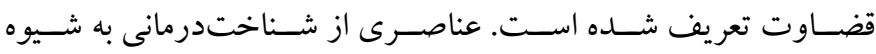

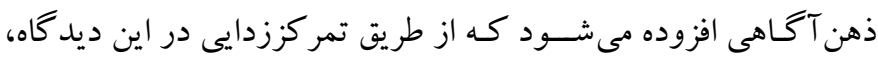

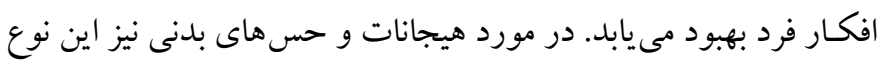

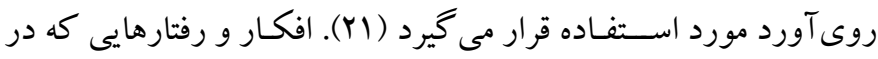
بدن يا ذهن خود فرد در حال وقوع هســتند و قبلاً ناهشـيار يا خود آيند

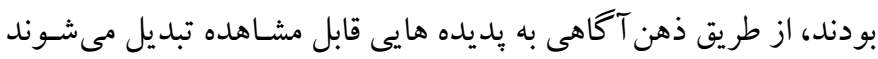

درمـان ذهن آكَاهى در جـامعههاى آمارى مختلف در بثزوهشهاى

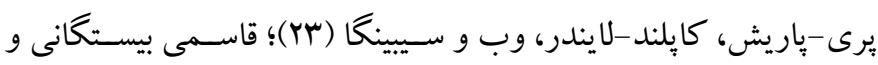

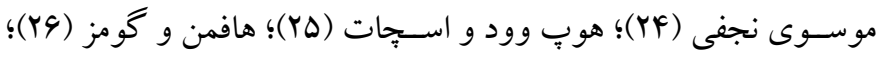
كروسـول و همكاران (YV)، و كروسـكا و همكاران (YN) مورد اسـتفاده

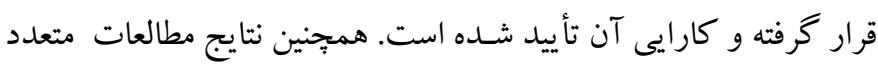

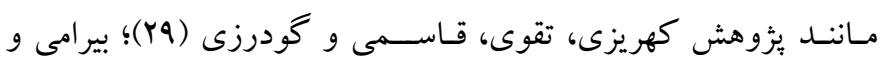

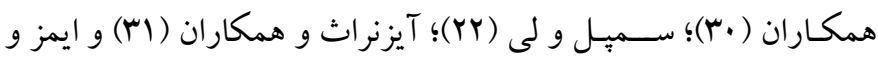

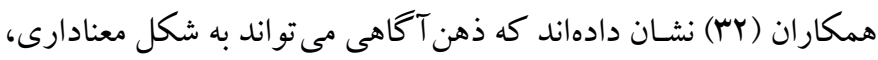

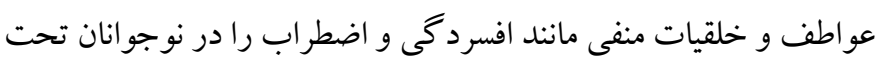

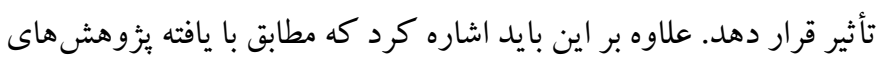

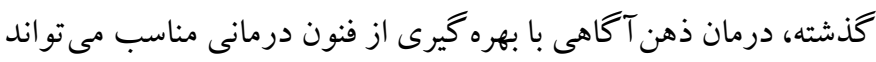

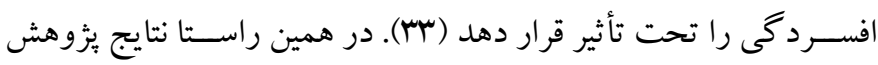

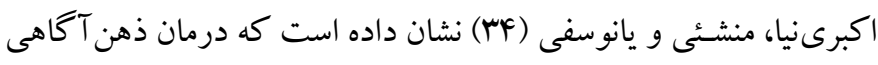
كود ككمحور بـا به كار گيرى اسـتعارههاى شــناختى مناسـبـ كود كان

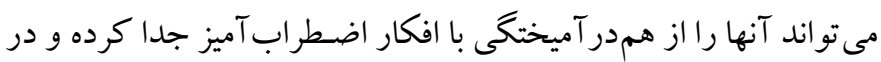

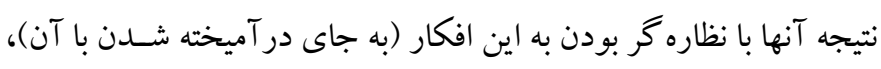
مى توانند اضطراب خود را كاهش دهند.

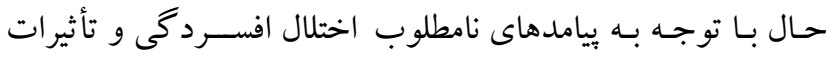

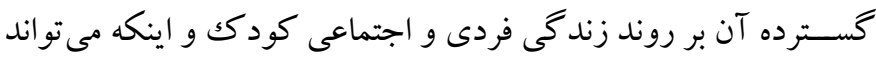

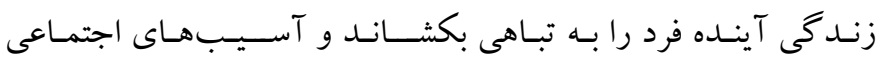

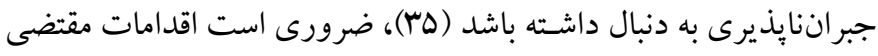

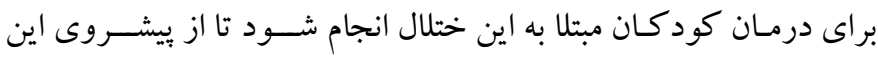

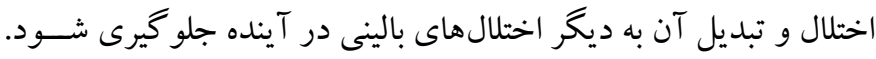

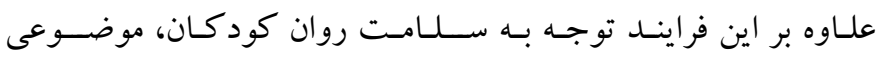


عدم همكارى و انجام ندادن تكاليف مشــخص شــده در كلاس، و عدم

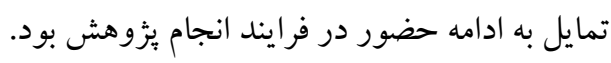

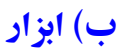

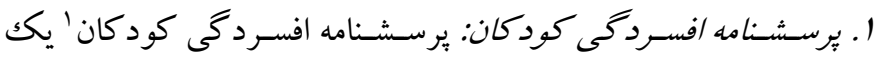
مقياس خود گزارشدهى است كه توسط كو اكس ب در سال 1999 ساخته

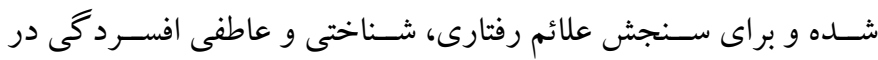

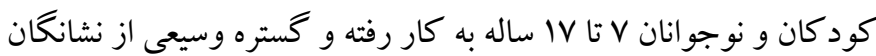

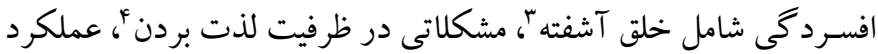

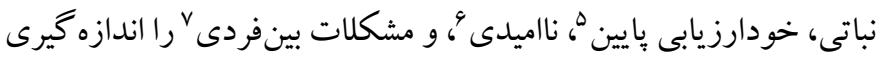

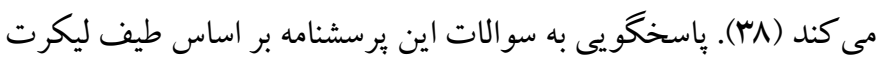

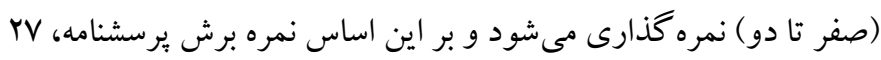

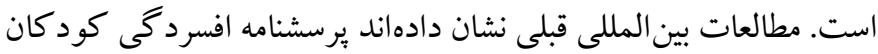

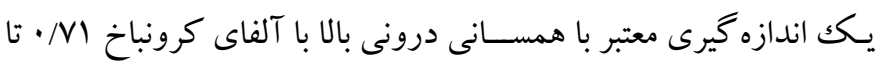

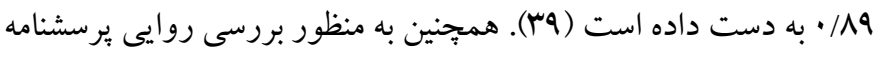

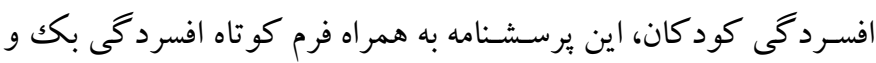

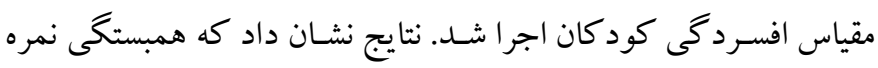

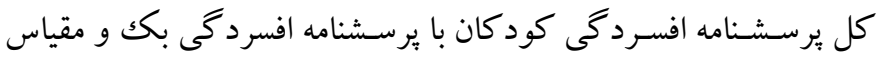

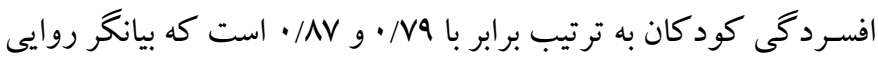

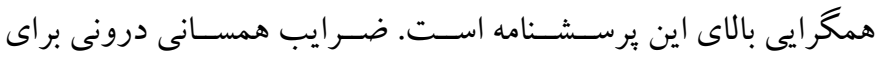

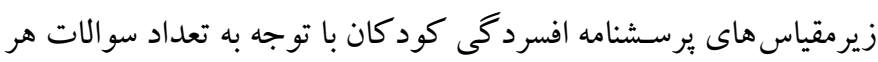

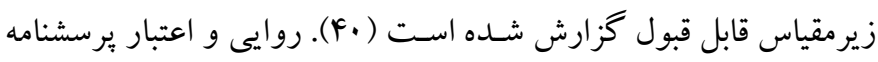
افسردگى كود كان در ايران نيز بررسى شده است. در مطالعهاى دهشيرى نرى و همكاران ضـريب اعتبار باز آزمايى و همسانى درونى را به ترتيب r بـ/.

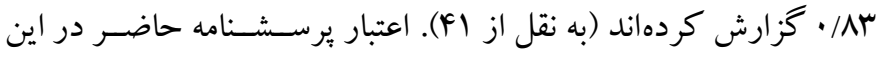

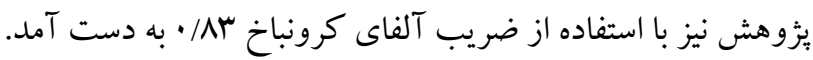

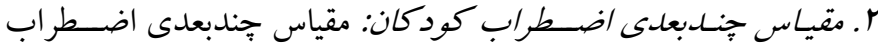

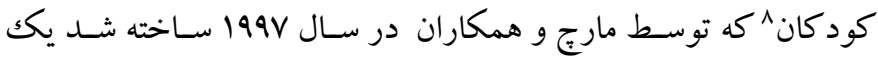

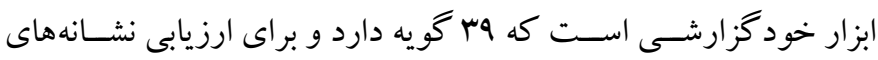

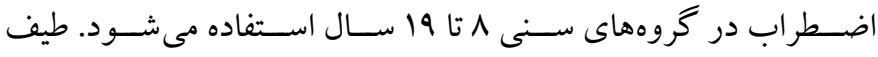

5. Interpersonal problems

6. Hopelessency

7. Interpersonal problems

8. Multidimensional Child Anxiety Scale
متخصص روانشناسى (دكتراى تخصصى روانشناسى) بر اساس بنجمين

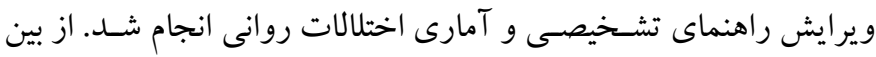

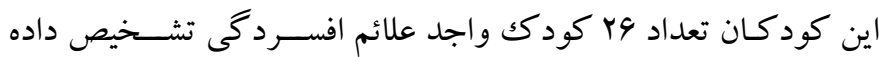

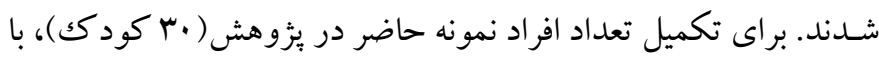

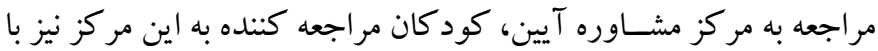

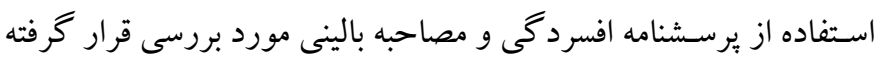

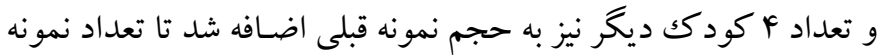

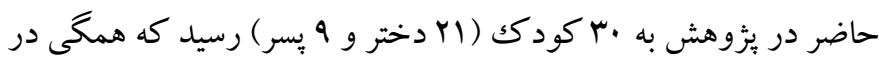

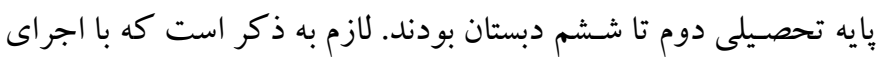
يرسشنامه اضطراب كود كان مشخص شد كه آنها داراى ميزان اضطراب بالاتر از نمره برش برسشنامه اضطراب هستند (كسب نمره بالاتر از هF در

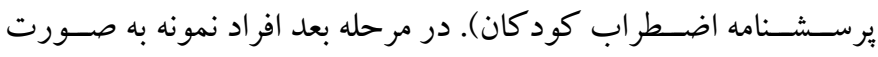

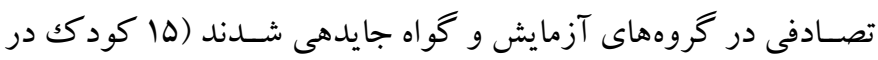

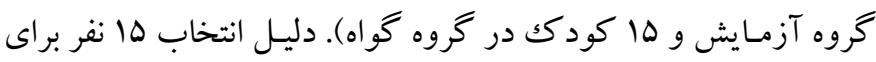
هر گروه، بر اساس منابع علمى مربوط بود (MV).

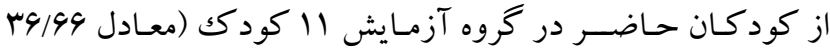

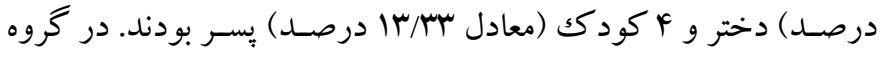

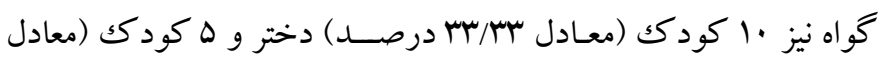

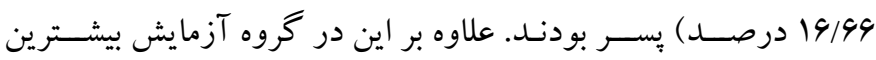

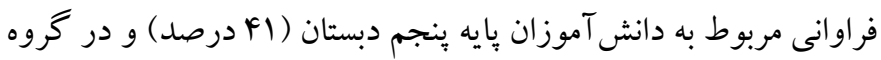

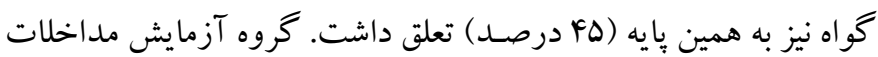

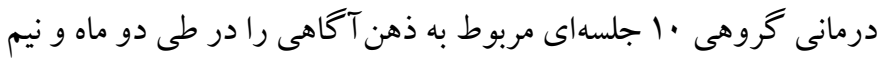

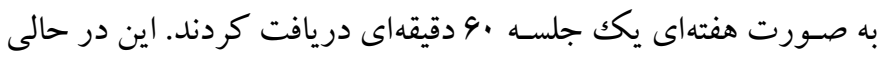

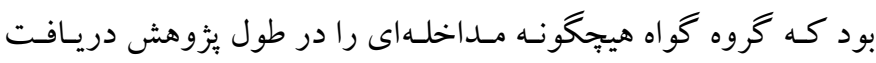

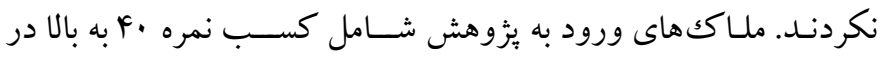

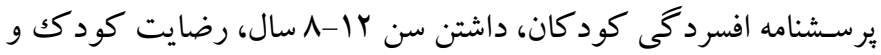

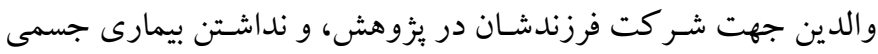

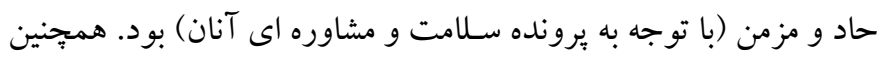
ملاكك هاى خروج از يزوهش نيز شـامل داشـتن بيش از دو جلسهـ غيبت،

1. Child Depression Questionnaire

2. Kovacs

3. Disturbed mode

4. Hedonic capacity 
همجنين روايى محتوايى اين ابزار در اين يُزوهش مطلوب كزارش شــده

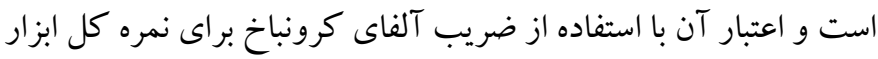

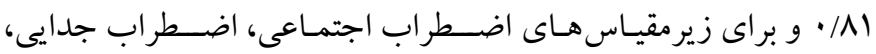

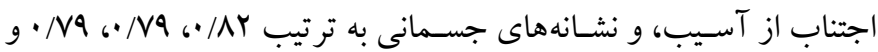

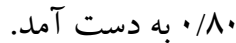
ج) برنـامه مداخلهاى: برنامه مداخلهاى بر كرفته از مداخله ذهن آكاهى

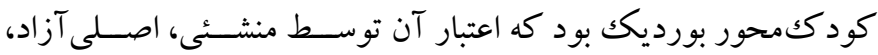

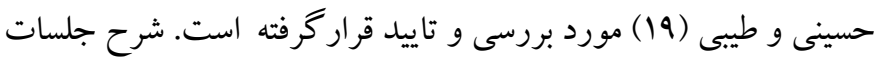

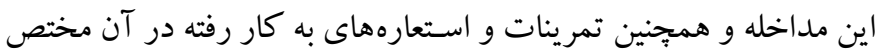

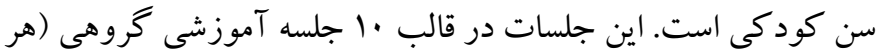

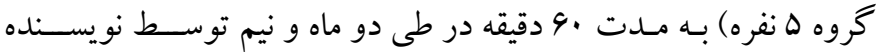

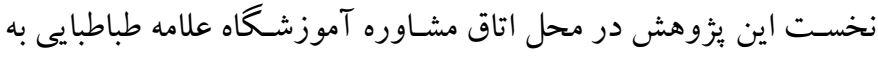
صورت هفتهاى يكك جلسه به شرح زير اجرا شد:
باسخكويى اين ابزار از نوع ليكرت (نمره صفر تا سه) است. حداقل نمره

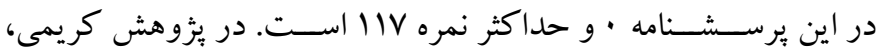

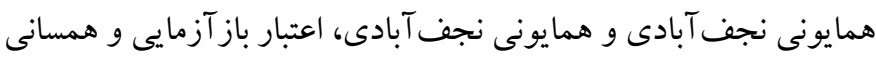

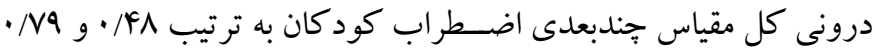

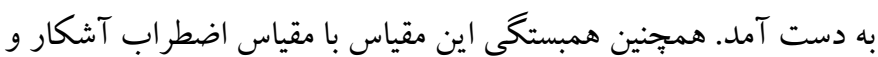

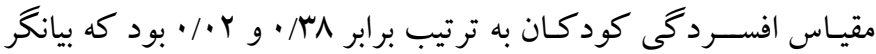

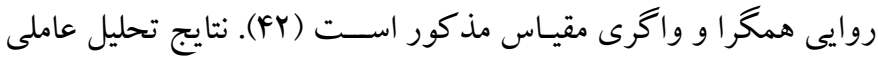

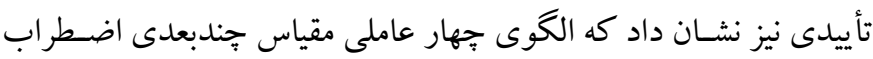

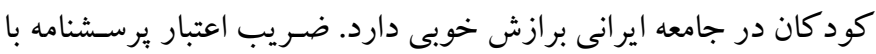
روش آلفاى كرونباخ NV/ • به دست آمد (FY). در مطالعه ايوارسون (Fr) براى كـل مقيـاس ضــريـب آلفـاى كرونبـاخ AV/ • و بر إى خردهمقيـاس

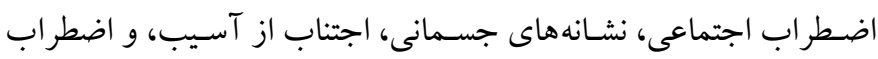

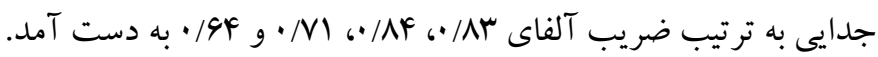

\section{جدول ا: خلاصه جلسات درمان ذهن آكاهى (19)}

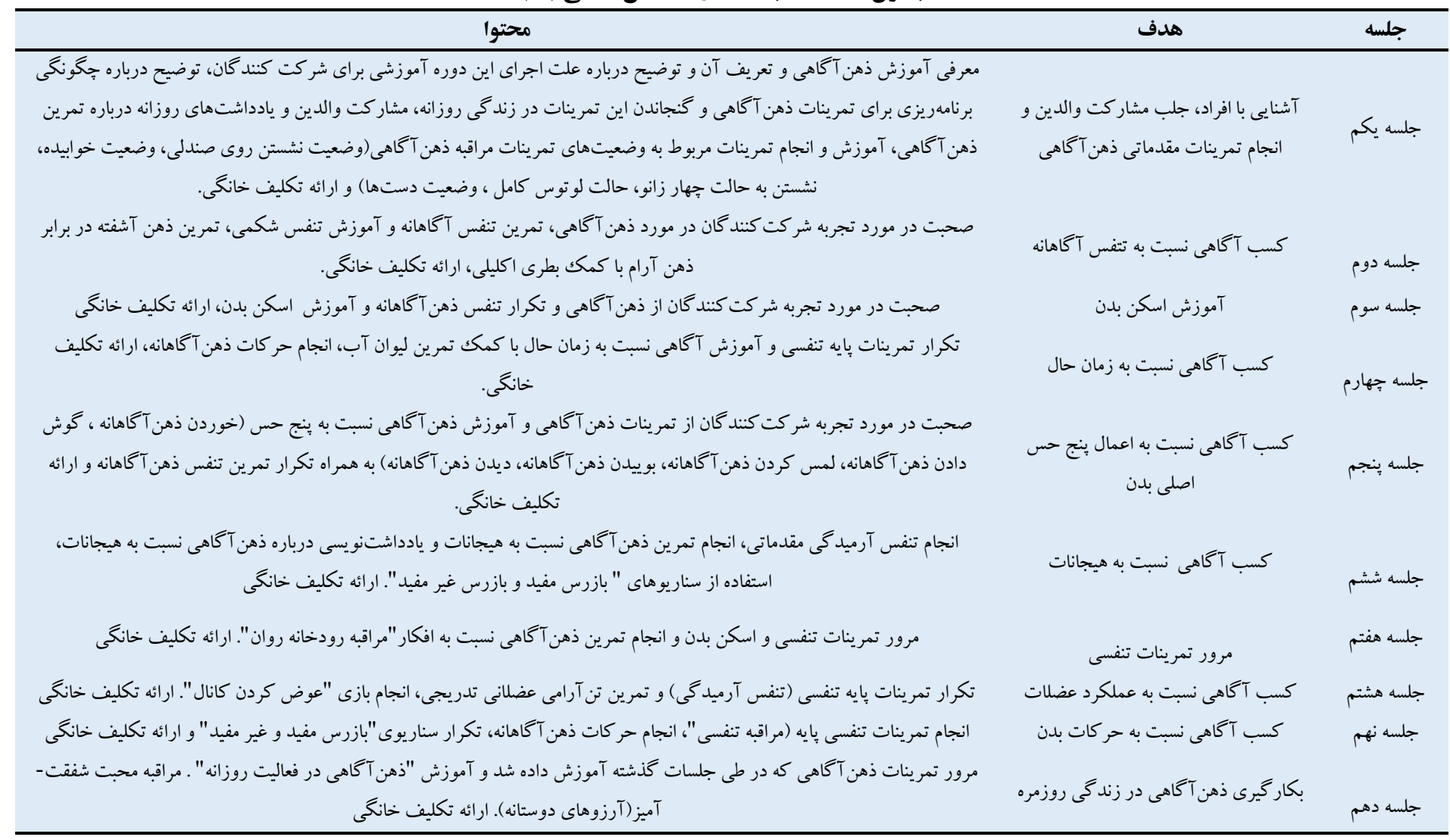




\section{يافته ها}

قبل از ارائه نتايج تحليل آزمون واريانس با تكرار سنجش، يِيشفرض هاى

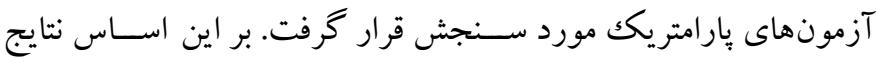

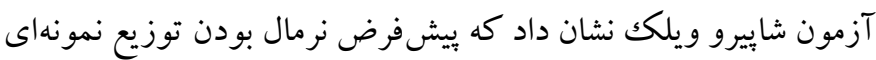

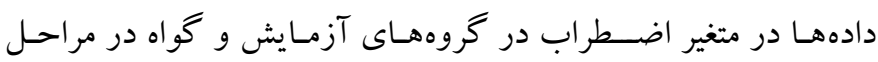

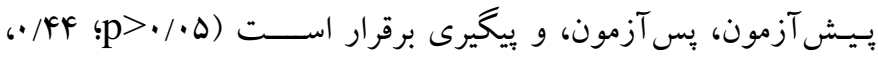
اس//F

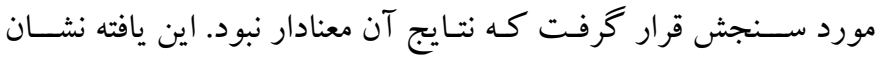

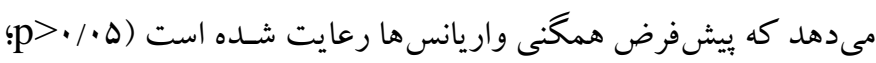

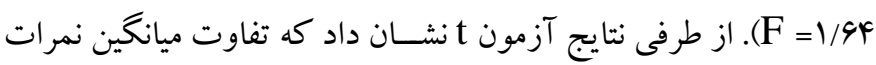

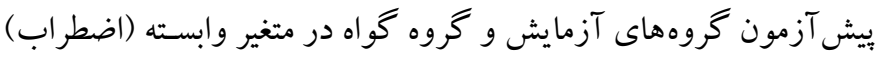

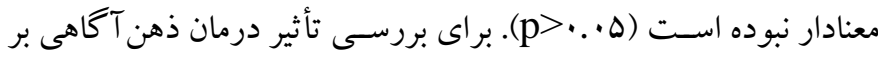

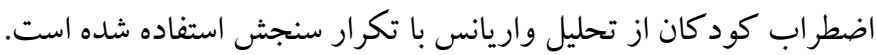

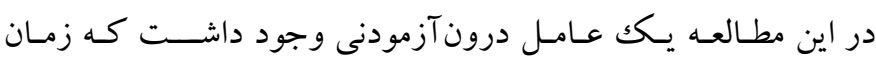

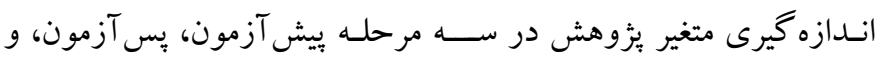

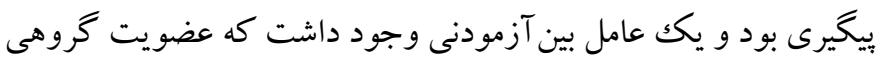

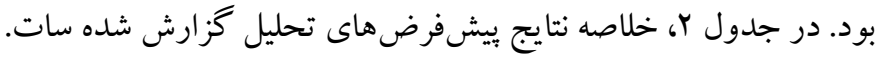

\section{جدول ז: جدول موجلى مبنى بر بررسى ييش فرض كرويت}

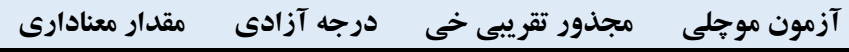

$\cdot / \mathrm{TV}$ $\mathrm{r} / 9 \mathrm{~V}$

بر اسـاس جـدول Y، نتايج آزمون مو جلى نشــان مىدهد كه بيشفرض

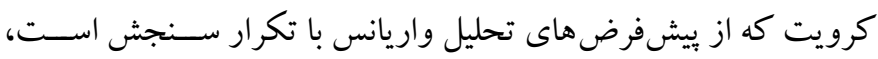

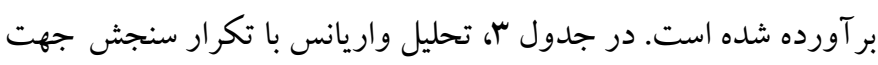

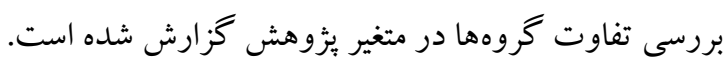

د) روش اجرا: جهت انجام بزوهش ابتدا هماهنخى هاى للازم با مسئولان

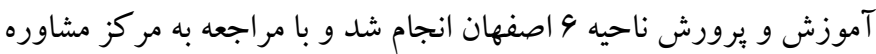

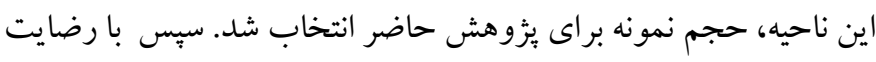

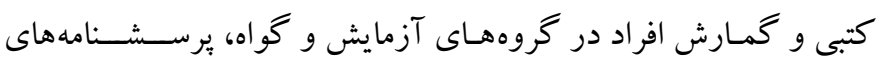

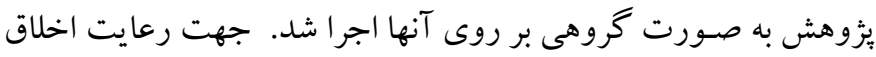

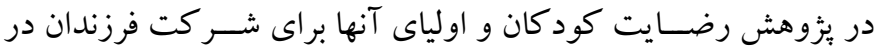

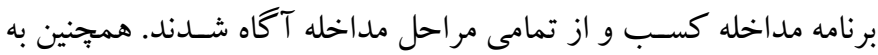

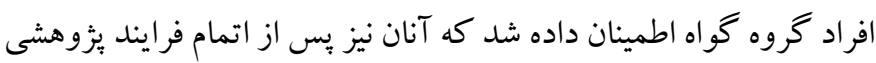

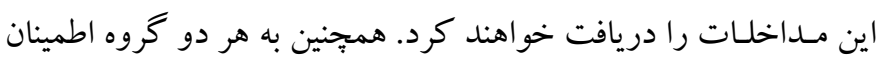
داده شد كه اطلاعات آنها محرمانه باقى مىماند و نيازى به درج نام نيست.

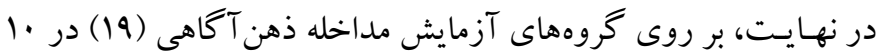

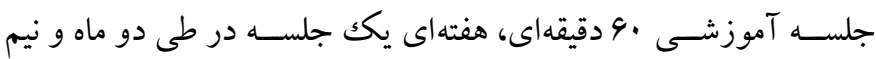

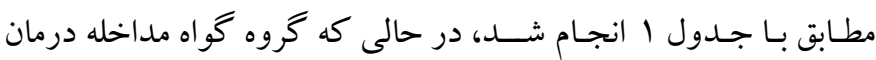

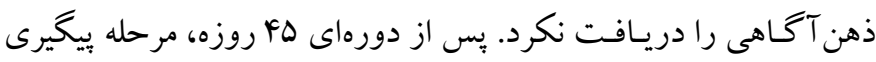
نيز اجرا شد.

در اين بزوهش بر اي تجزيه و تحليل دادهها از دو سطح آمار توصيفى

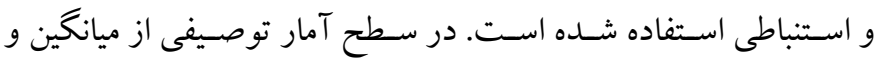

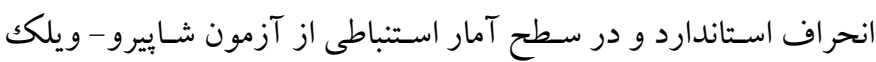

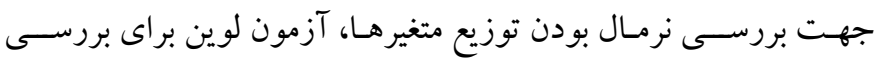

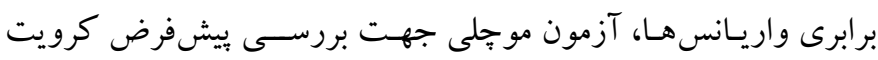

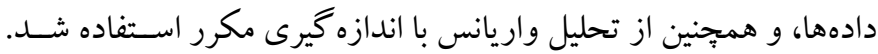

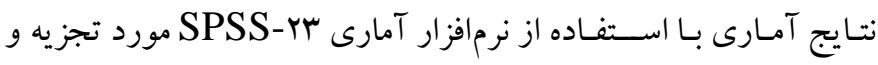
تحليل قرار گرفت.

جدول r: تحليل واريانس با تكرار سنجش جهت بررسى تفاوت كروهها در متغير ثزوهش

\begin{tabular}{|c|c|c|c|c|c|c|c|}
\hline توان آزمون & اندازه اثر & مقدار pa & مقدار f & ميانكين مجذورات & درجه آزادى & مجموع مجذورات & \\
\hline 1 & .191 &.$/ \cdots 1$ & $F F / G Y$ & $\Delta 99 / \cdot V$ & $r$ & $1 \% N / 10$ & مراحل \\
\hline 1 & . N4 & $\cdot / \cdots 1$ & 9)/M1 & $\mid F \cdot N / V$ & 1 & $\mid f \cdot N / I V$ & كروهبندى \\
\hline \multirow[t]{2}{*}{1} & $\cdot / \Delta r$ & $\% \cdot 1$ & $M / / Y F$ & $M Q \Lambda / F V$ & r & V৭द/9D & تعامل مراحل و گروهبندى \\
\hline & & & & $\mid r / v \Delta$ & $\Delta \varphi$ & VIF/YY & خطا \\
\hline
\end{tabular}


تفـاوت معنى دارى دارنــ. جهـت بررسـى تفـاوت درمان ذهن آكاهى با

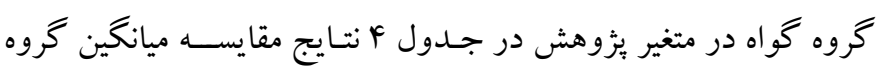

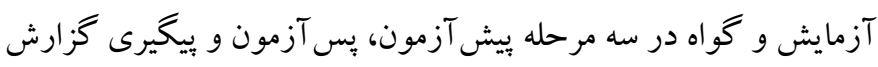

همان گونه كه نتايج جدول ب نشان مىدهد ميزان F اثر تعامل مراحل

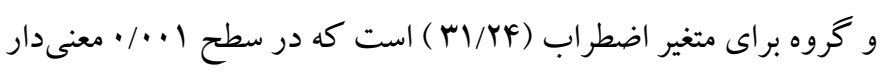

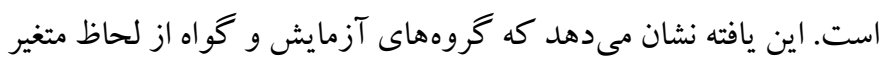

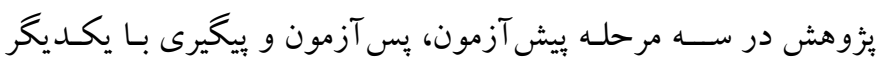

شده است.

جدول ع: نتايج مقايسه ميانكين كروه آزمايش و كواه در سه مرحله بيش آزمون، بس آزمون، و ييكيرى در متغير يزوهش

\begin{tabular}{|c|c|c|c|c|c|c|}
\hline سطح معنادارى & خطاى استاندارد بر آورد & تفاوت ميانكين ها & ميانكين كواه & ميانكين آزمايش & مرحله & مؤلفه \\
\hline$\cdot / \mathrm{Va}$ & $\cdot / M$ & $\cdot / 49$ & $\Delta 9$ & $\Delta 9 / 4 G$ & ييش آزمون & \\
\hline$\cdot / \cdots 1$ &.$/ 99$ & $11 / 4$. & $\Delta \Delta$ & $\mathrm{kT/q}$. & 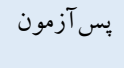 & اضطراب \\
\hline$\cdot / \cdots 1$ & $\cdot / A V$ & $I r / A$. & $\Delta F / G$. & $F I / A$. & ييخيرى & \\
\hline
\end{tabular}

يافتههاى بثزوهش آيزنراث و همكاران ( آY) درباره تأثير ذهن آكاهى بر

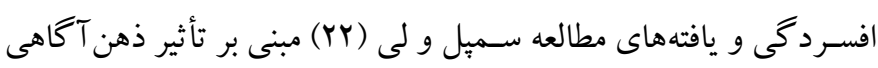

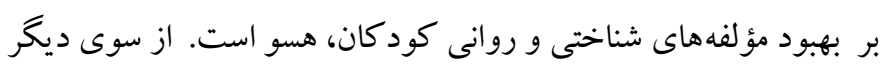

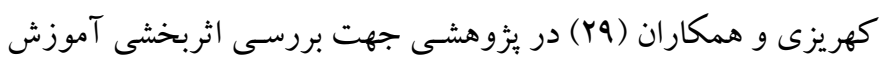

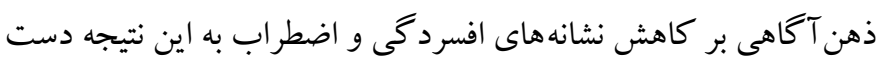

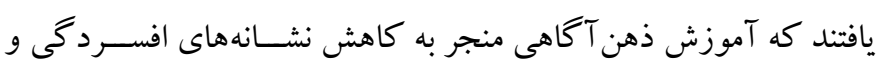

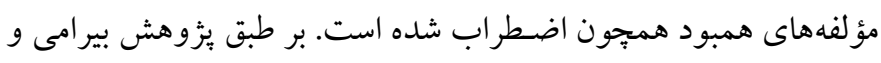

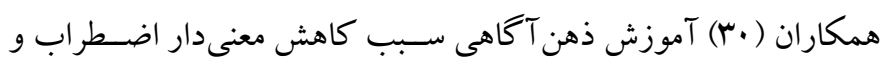

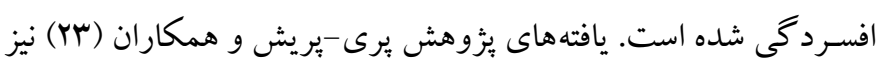

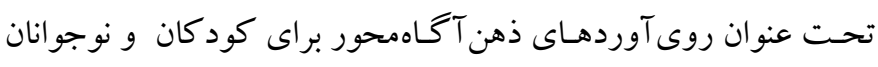

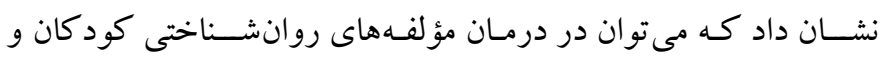
نوجوانان از اين شيوه استفاده كرد.

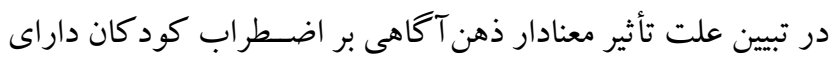

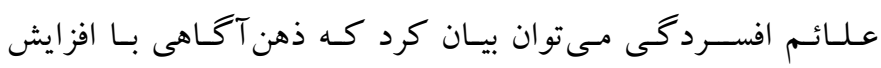

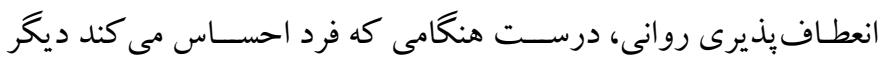

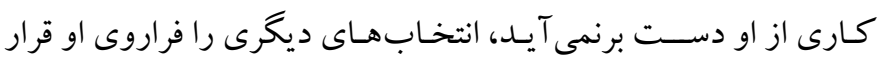

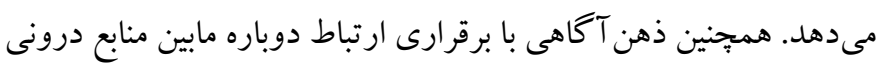

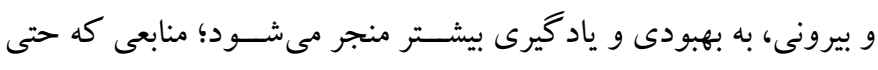

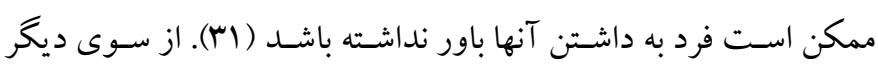

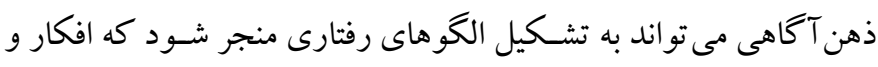

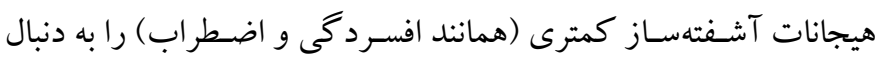

همان گونه نتايج جدول \& نشـان مىدهد، در متغير اضسطراب تفاوت

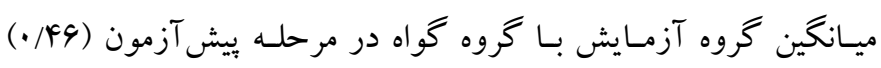

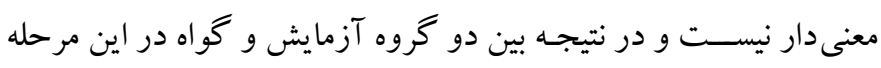

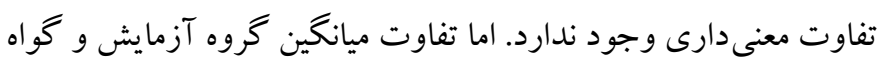

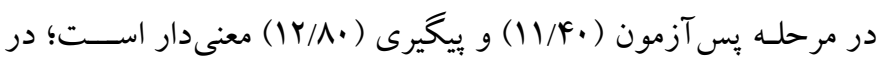

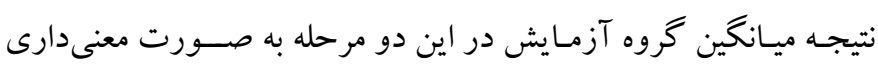
كمتر از ميانخين گروه گواه است.

\section{بحث و نتيجه كيرى}

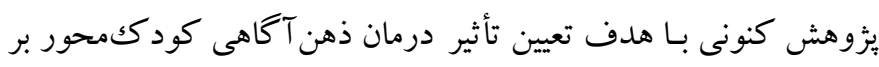

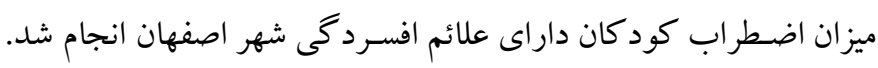

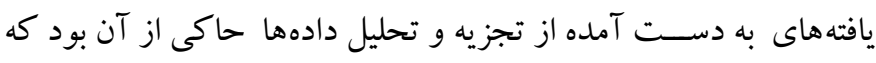

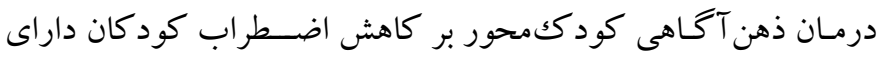

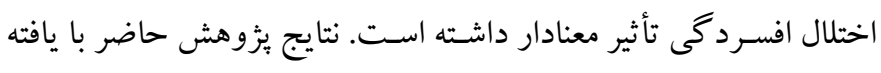

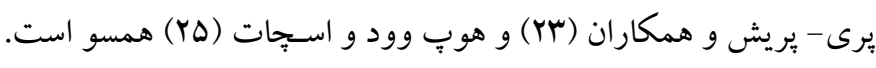

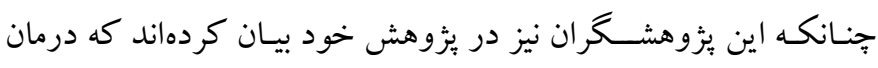

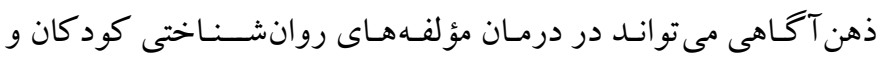

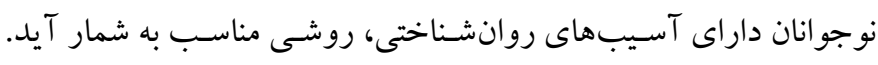

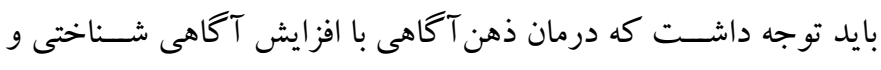

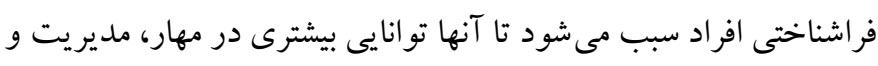

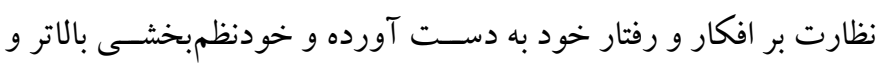

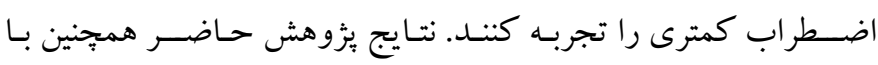


خود را در موقعيـتهـاى اجتمـاعى زنـدگى درگير كنتـــ امـا درمـان

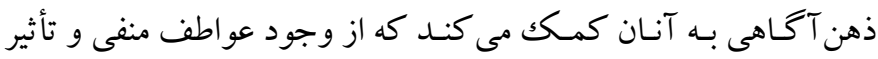

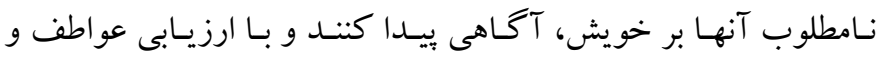

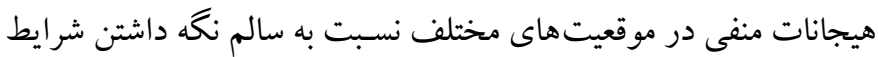

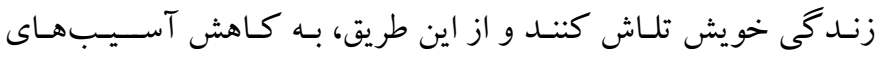
روانشناختى همجيون اضطراب، مبادرت ورزند.

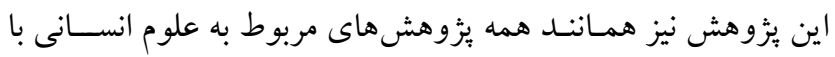

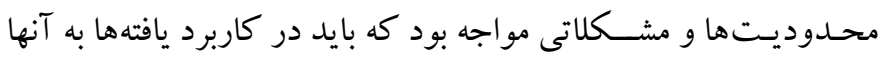
توجـه كرد. از جمله اين محدوديتها مى توان به اين موارد اشــاره كرد:

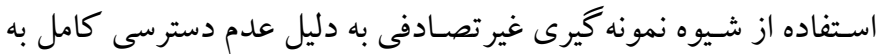

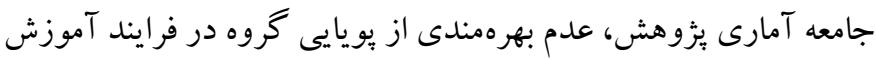

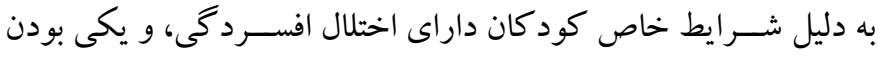

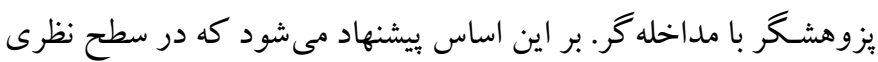

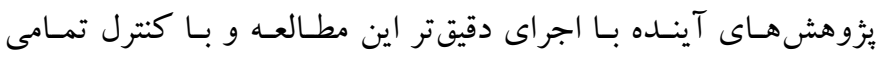

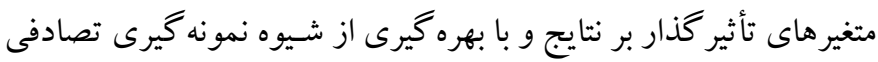
انجام شوند تا اعتبار بيرونى يثزوهش جهت تعميم يافتها و همجنين دقت نتايج به دسـت آمده افز ايش يابد. همجنين در سطح به كار بستهنه بيشنهاد

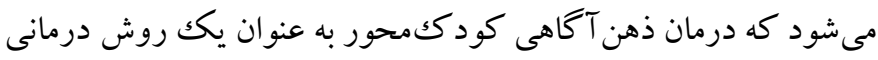
براى كاهش اضـطر اب كود كان مبتلا به افســردخى مورد اســتفاده قرار كيرد.

نتـايج حـاصـــل از ئزوهش نشـــان داد كـه درمـان ذهن آكَاهى

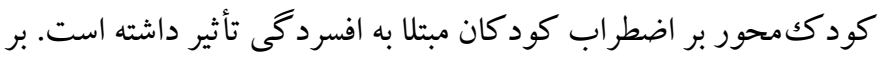

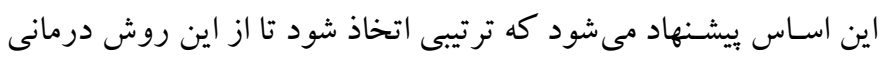

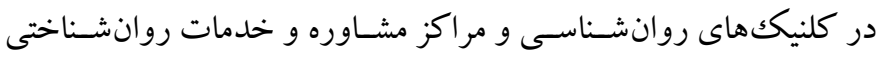

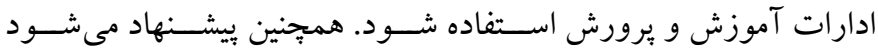
دورههاى ضــمن خدمت و كار گاههاى كاربردى و عملى (نه صــــاً در

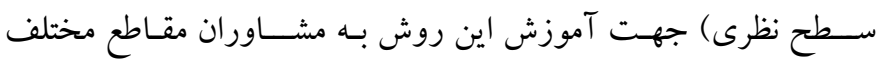

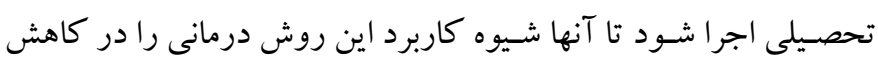

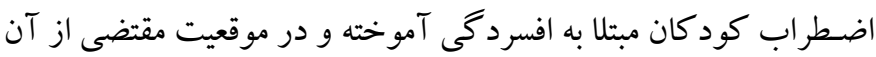

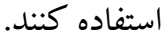

دارنــ (YF). همجينين وجود يـافتـهـاى بيشـــن بيـانكر آن اسـت كـه ذهن آكاهى مى تواند سـبب كاهش سـطح كورتيزول شـود (r) (Y). ديخر

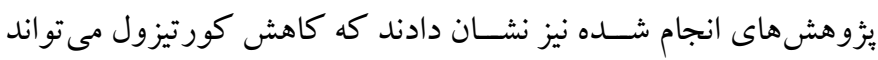

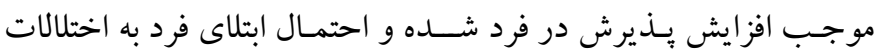

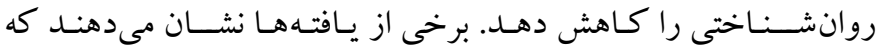

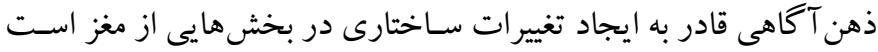
كه محر ككهاى حسى، شـناختى، و هيجانى را هردازش مى كنند (YD) و

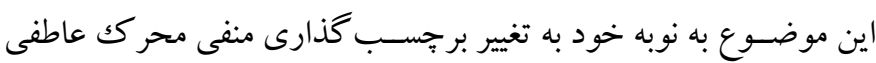

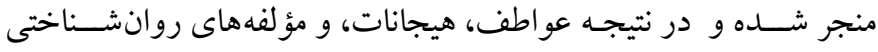
منفى مانند اضطراب، كاهش مى يابد. بايد اذعان داشت كه ذهن آكاهى باهي

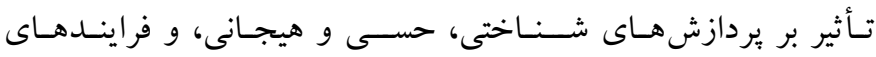

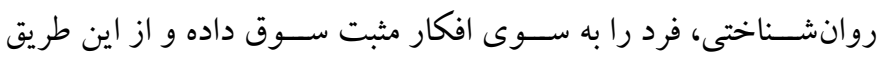

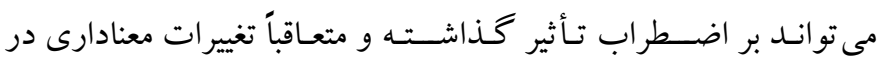
اضطراب كود كان داراى علائم افسردگى ايجاد كند.

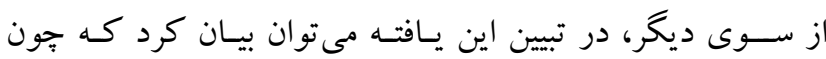

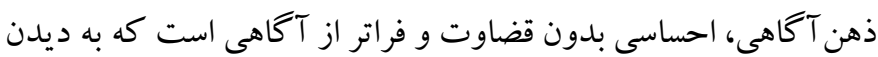

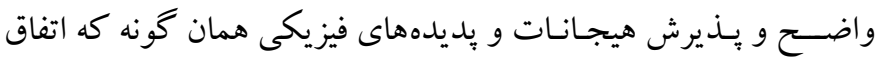

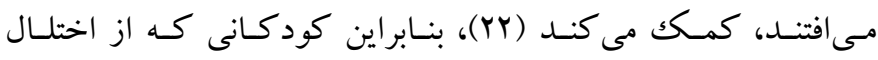

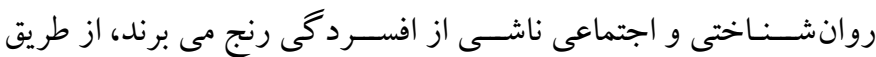

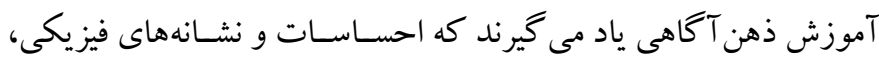
روانشناختى، و هيجانى خود را بذيرفته و در نتيجهى بذيرش احساسات،

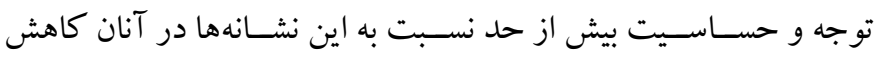

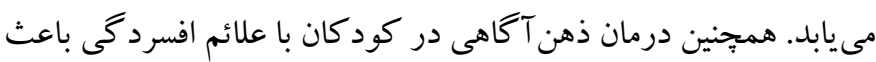

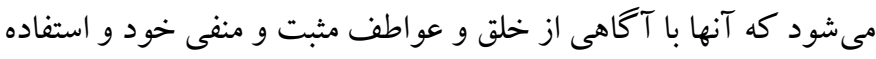

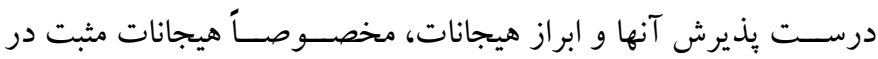
موقعيت هاى زندگىى، احسـاسـات منفى خويش را كاهش دهند كه در

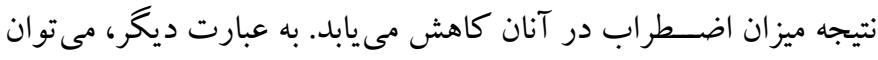

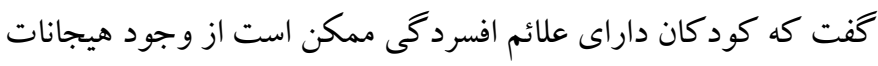

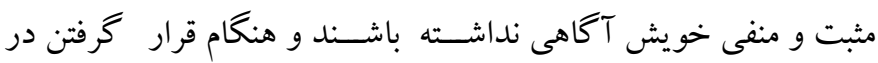
موقعيت هاى زندگى و اجتماعى نتواند به خوبى از هيجانات خود استى استفاده

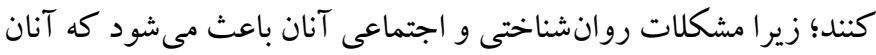
در موقعيت هاى اجتماعى، خود را به صسورت منفى ارزيابى كنند و كمتر 
دانش آموزان حاضر در بزوهش و همجنين مسئولان آموزش و برورش ناحيه 9 اصفهان، تقدير و تشكر مىشود. تضــاد منافع: در اين يُزوهش هيجِ گونه تعارض منافع توســ نويســند كان كز ارش نشده است.
تشكر و قدردانى: اين مطالعه بركرفته از بايان نامه كارشــاسى ارشد به شماره

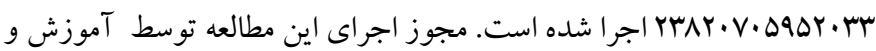

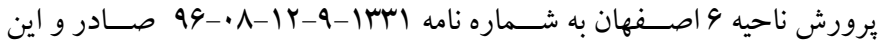
يروهش تحت نظارت گروه مشـاوره اين ناحيه انجام شـده اسـت. بدينوسيله از 


\section{References}

1. Angst J, Gamma A, Rossler W, Ajdacic V, Klein DN. Long-term depression versus episodic major depression: Results from the prospective Zurich study of a community sample. J Affect Disord. 2009; 115(1-2): 112-121. [Link]

2. Katon W, Lin EHB, Kroenke K. The association of depression and anxiety with medical symptom burden in patients with chronic medical illness. Gen Hosp Psychiatry. 2007; 29(2): 147-155. [Link]

3. Imel ZE, Malterer MB, McKay KM, Wampold BE. A meta-analysis of psychotherapy and medication in unipolar depression and dysthymia. J Affect Disord. 2008; 110(3): 197-206. [Link]

4. Satyanarayana S, Enns MW, Cox BJ, Sareen J. Prevalence and correlates of chronic depression in the Canadian community health survey: Mental health and well-being. Can J Psychiatry. 2009; 54(6): 389398. [Link]

5. Bromet E, Andrade LH, Hwang I, Sampson NA, Alonso J, De Girolamo G, et al. Cross-national epidemiology of DSM-IV major depressive episode. BMC Medicine. 2011; 9(1): 90. [Link]

6. Fallah R, Farhadi S, Amini K, Mohajeri M. Prevalence of depression in personnel of Zanjan university of medical sciences. Journal of Advances in Medical and Biomedical Research. 2011; 19(75): 107-113. [Persian]. [Link]

7. Raberts RE, Attkisson CC, Rosenblatt A. Prevalence of psychopathology among children and adolescents. Am J Psychiatry. 1998; 155(6): 715-725. [Link]

8. Liu Y, Merritt DH. Examining the association between parenting and childhood depression among Chinese children and adolescents: A systematic literature review. Child Youth Serv Rev. 2018; 88: 316-332. [Link]

9. Shoaf TL, Emslie GJ, Mayes TL. Childhood depression: Diagnosis and treatment strategies in general pediatrics. Pediatr Ann. 2001; 30(3): 130-137. [Link]

10. Kelvin R. Depression in children and young people. Paediatr Child Health. 2016; 26(12): 540-547. [Link]

11. Saleh J, Mahmoudi O, Paydar M. Efficacy of cognitive-behavioral therapy on the reduction of depression among students. Quarterly Journal of Child Mental Health. 2015; 2(1): 83-88. [Persian]. [Link]

12. Gould MS, Greenberg T, Velting DM, Shaffer D. Youth suicide risk and preventive interventions: A review of the past 10 years. J Am Acad Child Adolesc Psychiatry. 2003; 42(4): 386-405. [Link]
13. Abela JRZ, Hankin BL. Handbook of depression in children and adolescents. Guilford Press; 2008, pp: 74-75. [Link]

14. Chai XJ, Hirshfeld-Becker D, Biederman J, Uchida M, Doehrmann O, Leonard JA, et al. Functional and structural brain correlates of risk for major depression in children with familial depression. Neuroimage Clin. 2015; 8: 398-407. [Link]

15. Ghobari Bonab B, Motavalipoor A, Hakimirad E, Habibi Asgarabadi M. Relationship between anxiety and depression and magnitude of spirituality in students of the university of Tehran. Journal of Applied Psychology. 2009; 3(2): 110-123. [Persian]. [Link]

16. Whiteside SP, Brown AM. Exploring the utility of the spence children's anxiety scales parent- and childreport forms in a North American sample. J Anxiety Disord. 2008; 22(8): 1440- 1446. [Link]

17. Emadi Far F, Gorji Y. Effectiveness of attention training on attention control, focused attention and dispersed attention in girl students with test anxiety. Quarterly Journal of Child Mental Health. 2017; 4(1): 67-77. [Persian]. [Link]

18. Goldberger-Raskin BS, Gothelf D, Bachner-Melman R, Lang C, Kushnir J. The association between sleep disturbances of children with anxiety disorders and those of their mothers. Sleep Med. 2018; 43: 77-82. [Link]

19. Bordick D. Mindfulness skills for the children and adolescents. Monshe'ie GR, Asli Azad A, Hoseini L, Tayebi P. (Persian translator). First edition. Isfahan: Isfahan Islamic Azad University publication (Khorasgan); 2017, pp: 369-375. [Persian].

20. Miller CJ, Brooker B. Mindfulness programming for parents and teachers of children with ADHD. Complement Ther Clin Pract. 2017; 28: 108-115. [Link]

21. Kabat-Zinn J. Mindfulness-based interventions in context: Past, present, and future. Clin Psychol. 2003; 10(2): 144-156. [Link]

22. Semple RJ, Lee J. Chapter 8 - mindfulness-based cognitive therapy for children. In: Baer RA, editor. Mindfulness-based treatment approaches. Second Edition. San Diego: Academic Press; 2014, pp: 161188. [Link]

23. Perry-Parrish C, Copeland-Linder N, Webb L, Sibinga EMS. Mindfulness-based approaches for children and youth. Curr Probl Pediatr Adolesc Health Care. 2016; 46(6): 172-178. [Link]

24. Ghasemi Bistagani M, Musavi Najafi F. Effectiveness of child-centered mindfulness on social skills and self- 
efficacy of children with learning disabilities. Social Behavior Research \& Health. 2017; 1(2): 91-99. [Persian]. [Link]

25. Hopwood TL, Schutte NS. A meta-analytic investigation of the impact of mindfulness-based interventions on post traumatic stress. Clin Psychol Rev. 2017; 57: 12-20. [Link]

26. Hofmann SG, Gómez AF. Mindfulness-based interventions for anxiety and depression. Psychiatr Clin North Am. 2017; 40(4): 739-749. [Link]

27. Crosswell AD, Moreno PI, Raposa EB, Motivala SJ, Stanton AL, Ganz PA, et al. Effects of mindfulness training on emotional and physiologic recovery from induced negative affect. Psychoneuroendocrinology. 2017; 86: 78-86. [Link]

28. Kroska EB, Miller ML, Roche AI, Kroska SK, O'Hara MW. Effects of traumatic experiences on obsessive-compulsive and internalizing symptoms: The role of avoidance and mindfulness. J Affect Disord. 2018; 225: 326-336. [Link]

29. Kahrizi S, Taghavi M, Ghasemi R, Goodarzi M. The effectiveness of mindfulness-based cognitive therapy (MBCT) on depression, anxiety and somatic symptoms in asthma patients. Razi Journal of Medical Sciences. 2017; 24(154): 27-36. [Persian]. [Link]

30. Bayrami M, Movahedi Y, Mohammadzadigan R, Movahedi M, Vakili S. The effectiveness of group cognitive therapy based on mindfulness in reducing anxiety and depression in high school students. Journal of Psychological Achievements. 2013; 20(2): 1-18. [Persian]. [Link]

31. Eisendrath SJ, Gillung EP, Delucchi KL, Chartier M, Mathalon DH, Sullivan JC, et al. Mindfulness-based cognitive therapy (MBCT) versus the healthenhancement program (HEP) for adults with treatment-resistant depression: A randomized control trial study protocol. BMC Complement Altern Med. 2014; 14(1): 95. [Link]

32. Ames CS, Richardson J, Payne S, Smith P, Leigh E. Mindfulness-based cognitive therapy for depression in adolescents. Child Adolesc Ment Health. 2014; 19(1): 74-78. [Link]

33. Farhadi A, Movahedi Y, Kariminajad K, Movahedi $M$. The effect of mindfulness-based cognitive therapy on depression in male patients with coronary artery disease. Iranian Journal of Cardiovascular Nursing. 2014; 2(4): 6-14. [Persian]. [Link]
34. AkbariNia M, Manshaei GR, Yanousefi S. Effectiveness of child - centered mindfulness therapy on the depression and anxiety of the children with cancer after drug therapy. Journal of psychological Science. 2019; 18(76): 431-439. [Persian]. [Link]

35. Ferdinand RF, Stijnen T, Verhulst FC, Van Der Reijden M. Associations between behavioural and emotional problems in adolescence and maladjustment in young adulthood. J Adolesc. 1999; 22(1): 123-136. [Link]

36. Delavar A. Research methods in psychology and educational sciences. Third Edition. Tehran: Virayesh Pub; 2013, pp: 99-100. [Persian].

37. Asli Azad M, Manshaei G, Ghamarani A. The effect of mindfulness therapy on tolerance of uncertainty and thought-action fusion in patients with obsessivecompulsive disorder. Quarterly Journal of Child Mental Health. 2019; 6(1): 83-94. [Persian]. [Link]

38. Al-Balhan EM. The children's depression inventory as a reliable measure for post-Iraqi invasion Kuwaiti youth. Soc Behav Pers. 2006; 34(4): 351-366. [Link]

39. Ivarsson T, Svalander P, Oeystein L. The children's depression inventory (CDI) as measure of depression in Swedish adolescents: A normative study. Nord $\mathbf{J}$ Psychiatry. 2006; 60(3): 220-226. [Link]

40. Logan DE, Claar RL, Guite JW, Kashikar-Zuck S, Lynch-Jordan A, Palermo TM, et al. Factor structure of the children's depression inventory in a multisite sample of children and adolescents with chronic pain. The Journal of Pain. 2013; 14(7): 689-698. [Link]

41. Mohammadi K, Borjali A, Eskandari H, Delavar A. Clinical effectiveness of children's depression inventory for diagnosing depression disorder of children and adolescents. Journal of Clinical Psychology. 2010; 2(1): 1-8. [Persian]. [Link]

42. Karimi J, Homayuni Najafabadi S, Homayuni Najafabadi F. Psychometric properties of the multidimensional anxiety scale for children. Journal of North Khorasan University of Medical Sciences. 2015; 6(4): 885-894. [Persian]. [Link]

43. Ivarsson T. Normative data for the multidimensional anxiety scale for children (MASC) in Swedish adolescents. Nord J Psychiatry. 2006; 60(2): 107-113. [Link]

44. McCracken LM, Gauntlett-Gilbert J, Vowles KE. The role of mindfulness in a contextual cognitive-behavioral analysis of chronic pain-related suffering and disability. Pain. 2007; 131(1): 63-69. [Link] 